ABDIMAS: Jurnal Pengabdian Masyarakat Universitas Merdeka Malang
Vol.6(3) August 2021, 2021, 326-335
i-ISSN: 2721-138X e-ISSN: 2548-7159
Uttp://jurnal.unmer.ac.id/index.php/jpkm

\title{
Peningkatan Pengetahuan dan Minat Radiografer dalam Mengkonsumsi Gizi Seimbang di Era Pandemi COVID-19
}

\author{
Alpha Olivia Hidayati, Ayu Wita Sari \\ Departemen D-3 Radiologi, STIKES Guna Bangsa Yogyakarta \\ Jl. Padjajaran, Sleman, Daerah Istimewa Yogyakarta, 55283, Indonesia
}

\begin{abstract}
ARTICLE INFO
Received: 2021-01-25

Revised: 2021-03-21

Accepted: 2021-06-18

Keywords:

Balanced nutrition, Immunity, Knowledge, Radiografer

\section{ABSTRACT}

The consumption of foods that contain balanced nutrition is one way to increase immunity, especially during the COVID-19 pandemic. For this reason, it is necessary to raise awareness of the consumption of food with balanced nutrition for health workers, especially radiographers. One of the efforts that can be done is by providing education to increase radiographer knowledge and interest in consuming foods with balanced nutrition. This community service is in collaboration with IKMARA GUBAYO in the form of online counseling activities. Program evaluation is carried out quantitatively by calculating the frequency distribution of the knowledge level and interest before and after the activity. The results showed an increase in the level of participant's knowledge about balanced nutrition by $25,45 \%$ and an interest in implementing balanced nutrition consumption by $89 \%$. Participant's knowledge of balanced nutrition increased by $27,4 \%$, knowledge of fixed macro nutrient sources, knowledge of vitamin sources increased by $27,4 \%$, knowledge of the benefits of mineral substances increased by $27,2 \%$ and knowledge of how to increase immunity increased by $18,7 \%$. Providing education to radiographer online counseling can increase radiographer's knowledge and interest in consuming balanced nutrition as an effort to increase immunity during the COVID-19 pandemic.
\end{abstract}

(C)2021 Published by University of Merdeka Malang. This is an open access article distributed under the CC BY-SA 4.0 license (https://creativecommons.org/licenses/by-sa/4.0/)

How to cite: Hidayati, A. O., \& Sari, A. W. (2021). Peningkatan Pengetahuan dan Minat Radiografer dalam Mengkonsumsi Gizi Seimbang di Era Pandemi COVID-19. Abdimas: Jurnal Pengabdian Masyarakat Universitas Merdeka Malang, 6(3), 326-335. https://doi.org/10.26905/abdimas.v6i3.5351

\section{PENDAHULUAN}

Wabah COVID-19 melanda banyak negara di dunia dan kasus pertama dilaporkan di Kota Wuhan, China pada Desember 2019. Di Indonesia sendiri, laporan kejadian COVID-19 pertama kali pada bulan Maret 2019. COVID-19 yang disebabkan oleh Virus SARS-CoV-2 atau Virus Corona dapat menyerang siapa saja terutama orang dengan daya tahan tubuh yang lemah. Berdasarkan data Gugus Tugas Percepatan Penanganan COVID-19 Republik Indonesia, jumlah kasus terkonfirmasi positif sampai dengan 21 Desember 2020 adalah 664.930 orang dengan jumlah kematian mencapai 19.880 orang. Tingkat 


\section{Peningkatan Pengetahuan dan Minat Radiografer dalam Mengkonsumsi Gizi Seimbang di Era Pandemi COVID-19 \\ Alpha Olivia Hidayati, Ayu Wita Sari}

kematian (case fatality rate) yang diakibatkan COVID-19 adalah sekitar 3\%. Jika dilihat dari persentase angka kematian dilihat dari golongan usia, maka kelompok usia 46-59 tahun memiliki persentase angka kematian yang lebih tinggi dibandingkan golongan usia lainnya. Sedangkan berdasarkan jenis kelamin, $56,6 \%$ penderita yang meninggal akibat COVID-19 adalah laki-laki dan 43,4\% sisanya adalah perempuan (KPCPEN, 2020).

Sampai saat ini, cara yang dinilai efektif untuk mencegah semakin mewabahnya COVID-19 di masyarakat adalah dengan menggunakan masker, sering mencuci tangan pakai sabun atau menggunakan handsanitizer, menjaga jarak, dan menghindari kerumunan serta menjaga imunitas tubuh agar tetap baik. Berdasarkan panduan pencegahan penularan COVID-19 dalam Kementrian Kesehatan Republik Indonesia (2020), upaya peningkatan imunitas tubuh dapat dilakukan dengan konsumsi gizi seimbang, tidak merokok, mengkonsumsi suplemen vitamin jika diperlukan, melakukan aktivitas fisik atau olahraga, istirahat yang cukup, menghindari stres, serta pengendalian penyakit penyerta.

Tenaga kesehatan salah satunya radiografer menjadi garda terdepan dalam penanganan kasus COVID-19. Tenaga radiografer dituntut selalu siap dan sigap dalam menyediakan pemeriksaan penunjang berupa foto radiografi pasien termasuk didalamnya pasien COVID-19. Peningkatan jumlah pasien COVID-19 tentu saja akan meningkatkan beban kerja radiografer. Hal ini berdampak pada peningkatan tingkat kelelahan dan stres pada tenaga kesehatan, termasuk di dalamnya radiografer. Berdasarkan Keputusan Menteri Kesehatan Republik Indonesia No. 1014/Menkes/SK/XI/2008 tentang Standar Pelayanan Radiologi Diagnostik, dapat diketahui bahwa beban kerja radiografer berdasaran kebutuhan jumlah radiografer adalah 2 orang per alat untuk semua tipe rumah sakit. Jika melihat aturan tersebut, maka radiografer rata-rata membutuhkan waktu melakukan tugas pokok pemeriksaan 18 menit per pemeriksaan dengan jumlah pemeriksaan sebanyak 29 pemeriksaan per hari. Namun, dikarenakan kondisi pandemi COVID-19 saat ini, menuntut radiografer melakukan pekerjaan dengan beban kerja berlebih. Berdasarkan penelitian Kurniawati \& Solikhah (2012), kelelahan kerja pada tenaga kesehatan dapat menurunkan kinerja tenaga kesehatan secara signifikan sebesar 2,26\%. Penelitian Haryanti et al. (2013) dan Runtu et al. (2018) menunjukkan bahwa beban kerja yang berlebih berhubungan dengan kejadian stres pada tenaga kesehatan. Padahal timbulnya kelelahan dan stres dapat mengakibatkan penurunan imunitas tubuh (Mayasari \& Pratiwi, 2009). Selain itu, sebagai garda terdepan menyebabkan radiografer harus sering kontak langsung dengan para pasien dan keluarga pasien. Pada kondisi ini, pasien sering kali belum diketahui dengan pasti kondisinya, apakah terpapar COVID-19 atau tidak. Hal ini menjadi tantangan tersendiri bagi para radiografer. Radiografer diharapkan mampu menjaga kondisi imunitas tubuhnya di tengah paparan penyakit yang ada di sekitarnya.

Seseorang dapat terinfeksi penyakit, jika agen kausal penyakit infeksi terpapar pada individu kemudian memasuki tubuh, melakukan multiplikasi dan maturasi, menimbulkan perubahan patologi yang terdeteksi secara laboratoris atau terlihat secara klinis. Ukuran yang menunjukkan kemampuan agen penyakit untuk mempengaruhi riwayat alamiah penyakit adalah infektivitas, patogenitas, dan virulensi. Untuk itu perlu dilakukan suatu usaha yang bertujuan untuk mencegah, menunda, mengurangi, membasmi, mengeliminasi, penyakit dan kecacatan, dengan menerapkan sebuah atau sejumlah intervensi yang telah dibuktikan efektif. Pencegahan yang dilakukan dapat berupa pencegahan primer, pencegahan sekunder, dan pencegahan tersier. Pada pencegahan tersier dapat dilakukan dengan pengobatan, 
ABDIMAS: Jurnal Pengabdian Masyarakat Universitas Merdeka Malang Volume 6, No. 3, August 2021: 326-335

rehabilitasi, dan pembatasan kecacatan. Pencegahan sekunder dapat dilakukan dengan deteksi dini dan pengobatan segera. Sedangkan, pada pencegahan primer dilakukan dengan memodifikasi determinan, faktor resiko, promosi kesehatan, dan perlindungan spesifik. Salah satunya dengan cara peningkatan imunitas tubuh melalui kebiasaan mengkonsumsi makanan dengan gizi seimbang (Najmah, 2015).

Konsumsi makanan yang mengandung gizi seimbang menjadi salah satu cara meningkatkan imunitas tubuh terutama di masa pandemi COVID-19 (Hidayah et al., 2020). Konsumsi gizi seimbang merupakan konsumsi makanan sehari-hari yang mengandung zat gizi dalam jumlah dan jenis yang sesuai dengan kebutuhan tubuh dengan prinsip keanekaragaman makanan (Pratami et al., 2016). Ketika makanan yang dikonsumsi tidak mengandung gizi seimbang maka akan mepengaruhi status gizi seseorang. Kekurangan gizi akan menyebabkan seseorang mengalami gagal tumbuh, terganggunya perkembangan, menurunkan produktivitas kerja, serta dapat berakibat pada morbiditas karena penurunan imunitas tubuh dan mortalitas (Andriani \& Wijatmadi, 2012).

Makanan yang mengandung gizi seimbang berarti makanan yang dikonsumsi mengandung zat gizi yang lengkap untuk menjamin metabolisme tubuh berjalan dengan baik. Faktor gizi memegang peranan penting dalam pertumbuhan, kecerdasan, pencegahan terhadap infeksi, produktivitas kerja, dan pencegahan terhadap penyakit kronis. Dalam mengkonsumsi makanan dengan gizi seimbang harus menerapkan prinsip pertama dari gizi seimbang, yaitu membiasakan makan makanan beraneka ragam. Hal ini dikarenakan tidak ada suatu makanan yang mengandung seluruh zat gizi yang diperlukan tubuh, kecuali ASI untuk bayi hingga umur 6 bulan. Pola makan dengan gizi seimbang bukan hanya memperhatikan sumber zat gizi makro (karbohidrat, lemak, dan protein) tapi juga zat gizi mikro, seperti vitamin dan mineral (Yosephin, 2018). Karbohidrat sebagai sumber energi utama memerlukan keterlibatan hormon insulin dan tiamin (Vitamin B1) dalam proses metabolismenya. Sedangkan hormon insulin sendiri sangat memerlukan protein dalam pembentukannya. Selain sebagai zat pengatur dan pemeliharaan jaringan tubuh, protein juga berperan dalam transport zat gizi seperti vitamin A, mangan (Mn), dan besi (Fe). Sedangkan vitamin dan mineral yang lain juga berperan dalam metabolisme karbohidrat, lemak, dan protein (Muchtadi, 2009).

Seringkali dikarenakan beban kerja yang tinggi dan stres menyebabkan penurunan nafsu makan, apalagi harus makan makanan dengan gizi seimbang. Untuk itu perlu ditumbuhkan kesadaran konsumsi makanan dengan gizi seimbang bagi tenaga kesehatan khususnya radiografer. Pembentukan perilaku yang baik berupa kebiasaan konsumsi makanan dengan gizi seimbang sangat dipengaruhi oleh faktor internal dan eksternal, salah satunya adalah pengetahuan (Prasetiya, 2015). Penelitian Agustin et al. (2018) dan Yurni \& Sinaga (2017) menunjukkan pengetahuan gizi seimbang subjek meningkat setelah diberikan intervensi pendidikan gizi dan berpengaruh pula terhadap sikap, perilaku, dan status gizi subjek. Berdasarkan kondisi tersebut, diperlukan pemberian edukasi tentang gizi seimbang kepada para tenaga kesehatan khususnya radiografer agar mau menerapkan konsumsi makanan dengan gizi seimbang sehingga imunitas tetap baik yang berakibat pada produktivitas kerja yang tetap terjaga dan tidak mudah terinfeksi penyakit terutama COVID-19.

IKMARA GUBAYO (Ikatan Mahasiswa Alumni Radiologi Guna Bangsa Yogyakarta) adalah suatu komunitas radiografer muda lulusan Program Studi D3 Radiologi STIKES Guna Bangsa Yogyakarta 


\section{Peningkatan Pengetahuan dan Minat Radiografer dalam Mengkonsumsi Gizi Seimbang di Era Pandemi COVID-19 \\ Alpha Olivia Hidayati, Ayu Wita Sari}

angkatan 1 sampai dengan angkatan 3. Sebagian besar alumni telah bekerja di rumah sakit seluruh Indonesia. Rata-rata radiografer berumur dibawah 40 tahun dengan masa kerja rata-rata 2 tahun. Komunitas ini beranggotakan 63 anggota aktif yang sering berbagi pengalaman dan keilmuwan melalui group Whatsapp. Berdasarkan hasil observasi di lapangan, pada masa pendemi COVID-19 ini, rata-rata mereka bekerja 9 jam sehari dengan jumlah pemeriksaan 30-40 pemeriksaan per hari. Hal ini, terjadi karena jumlah pasien yang melonjak tajam sedangkan tenaga radiografer masih kurang. Kondisi ini dapat menyebabkan penurunan imunitas tubuh karena faktor stres dan kelelahan. Selain itu, lebih dari 50\% dari mereka mempunyai kebiasaan mengkonsumsi makanan yang tidak mengandung gizi seimbang, rata-rata mereka kurang mengkonsumsi sayur dan buah. Hal inilah yang mendorong kami tenaga pendidik untuk melakukan pengabdian masyarakat kepada mereka.

Pengabdian kepada masyarakat ini dilaksanakan dengan tujuan dapat meningkatkan pengetahuan dan minat tenaga radiografer yang tergabung dalam IKMARA GUBAYO untuk mengkonsumsi makanan dengan gizi seimbang agar para radiografer mempunyai imunitas yang baik sehingga dapat menjalankan tugas dengan baik dan tidak mudah terinfeksi Virus Corona. Program ini dilaksanakan sebagai bentuk kontribusi tenaga pendidik kepada masyarakat dalam mendukung penanganan pandemi COVID-19. Para alumni yang tergabung dalam Ikatan Mahasiswa Radiologi Stikes Guna Bangsa Yogyakarta sebagai para radiografer muda diharapkan dapat memberikan contoh melalui penerapan konsumsi makanan dengan gizi seimbang terutama di lingkungan kerja masing-masing.

\section{METODE}

Pengabdian kepada masyarakat ini dilaksanakan sebagai program bersama dosen Program Studi D3 Radiologi STIKES Guna Bangsa Yogyakarta dengan Ikatan Mahasiswa Alumni Radiologi Guna Bangsa Yogyakarta (IKMARA GUBAYO) dalam bentuk seminar dan diskusi yang bernama "IKMARA TALK Series 1". Sasaran dari kegiatan ini adalah radiografer alumni dari Program Studi D3 STIKES Guna Bangsa Yogyakarta. Waktu yang diperlukan dari mulai persiapan kegiatan hingga evaluasi kegiatan dilaksanakan dalam kurun waktu 2 minggu. Kegiatan ini dilaksanakan secara daring melalui platform Zoom yang diikuti oleh 59 radiografer yang tergabung dalam IKMARA GUBAYO. Program ini dilaksanakan melalui tiga tahap, yaitu perencanaan, pelaksanaan, dan evaluasi.

Pada tahap perencanaan dilakukan diskusi dan pembahasan rencana kegiatan dengan pengurus IKMARA GUBAYO secara daring. Tahap perencanaan dilaksanakan mulai tanggal 20 November 2021. Setelah diputuskan konsep kegiatan, kemudian dilakukan proses perizinan pelaksanaan kegiatan dan promosi kegiatan melalui media sosial berupa Instagram, web STIKES Guna Bangsa dan Whatsapp Group alumni IKMARA GUBAYO dengan cara menyampaikan brosur kegiatan. Sasaran dalam kegiatan ini adalah radiografer muda yang tergabung dalam IKMARA GUBAYO yang bekerja di rumah sakit dan klinik. Untuk mengikuti kegiatan ini, para radiografer diminta untuk mendaftar melalui link pendaftaran https://bit.ly/PenyuluhanalumniGBY. Gambar 1 menunjukkan brosur dan susunan acara kegiatan pengabdian masyarakat. 
ABDIMAS: Jurnal Pengabdian Masyarakat Universitas Merdeka Malang Volume 6, No. 3, August 2021: 326-335

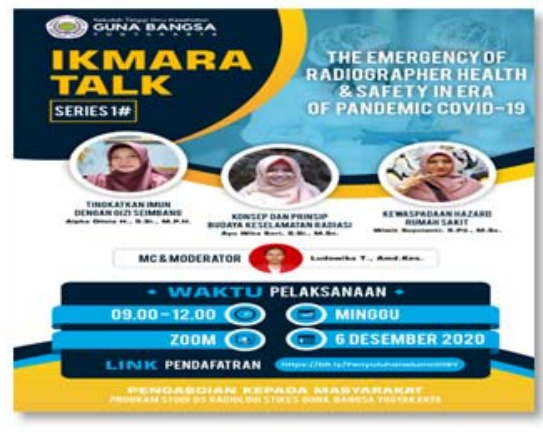

Gambar 1. Brosur kegiatan pengabdian kepada masyarakat

Tabel 1. Susunan acara kegiatan seminar online dalam rangka pengabdian kepada masyarakat

\begin{tabular}{|c|c|c|}
\hline Agenda Kegiatan & Pukul & Pelaksana Kegiatan \\
\hline Pembukaan & $09.00-09.10$ & $\mathrm{MC}$ \\
\hline Pre test & $09.10-09.30$ & MC \\
\hline Pembacaan CV pemateri 1 & $09.30-09.35$ & Moderator \\
\hline $\begin{array}{l}\text { Materi } 1 \\
\text { "Tingkatkan Imun dengan Gizi Seimbang" }\end{array}$ & $09.35-10.05$ & Alpha Olivia Hidayati, S.Si., M.P.H. \\
\hline Pembacaan CV pemateri 2 & $10.05-10.10$ & Moderator \\
\hline $\begin{array}{l}\text { Materi } 2 \\
\text { "Konsep dan Prinsip Budaya Keselamatan Radiasi" }\end{array}$ & $10.10-10.40$ & Ayu Wita Sari, S.Si., M.Sc. \\
\hline Pembacaan CV pemateri 3 & $10.40-10.45$ & Moderator \\
\hline $\begin{array}{l}\text { Materi } 3 \\
\text { "Kewaspadaan Hazard Rumah Sakit" }\end{array}$ & $10.45-11.15$ & Wiwit Sepvianti, S.Pd., M.Sc. \\
\hline Tanya Jawab & $11.15-11.45$ & Moderator \\
\hline Post Test & $11.45-12.00$ & $M C$ \\
\hline Foto bersama dan Penutup & $12.00-12.10$ & $\mathrm{MC}$ \\
\hline
\end{tabular}

Tahap selanjutnya dari rangkaian kegiatan ini adalah pelaksanaan kegiatan. Kegiatan pengabdian kepada masyarakat dilaksanakan dengan memberikan edukasi tentang gizi seimbang melalui audio visual aids dengan platform Zoom. Pemilihan alat edukasi ini didasarkan pada kondisi pandemi COVID-19 yang tidak memungkinkan untuk melakukan kegiatan bersama dan berkumpul. Dalam pelaksanaannya, peserta diminta untuk bergabung melalui link Zoom yang sudah dibagikan melalui grup Whatsapp. Pada awal kegiatan, peserta diberikan penjelasan tentang teknis acara yang akan berlangsung. Sebelum pemberian edukasi, peserta diminta untuk mengerjakan soal pre-test tentang gizi seimbang. Gizi seimbang disini adalah kebiasaan para radiografer yang tergabung dalam IKMARA GUBAYO dalam mengkonsumsi makanan yang mengandung karbohidrat, lemak, protein, vitamin, dan mineral dengan jumlah sesuai kebutuhan yang dibagikan dalam bentuk Google Form https://forms.gle/PkTMe4UEi2WyqopM9 
Setelah mengerjakan pre-test, peserta menyimak penjelasan tentang apakah yang dimaksud dengan gizi seimbang, mengapa kita harus menerapkan gizi seimbang pada pola makan harian kita serta apa manfaat menerapkan konsumsi gizi seimbang dalam kehidupan sehari-hari terutama dalam masa pandemi COVID-19 sekarang ini. Peserta mengajukan pertanyaan pada sesi tanya jawab setelah penyampaian materi. Berikut gambaran pelaksanaan kegiatan pengabdian kepada masyarakat secara daring.
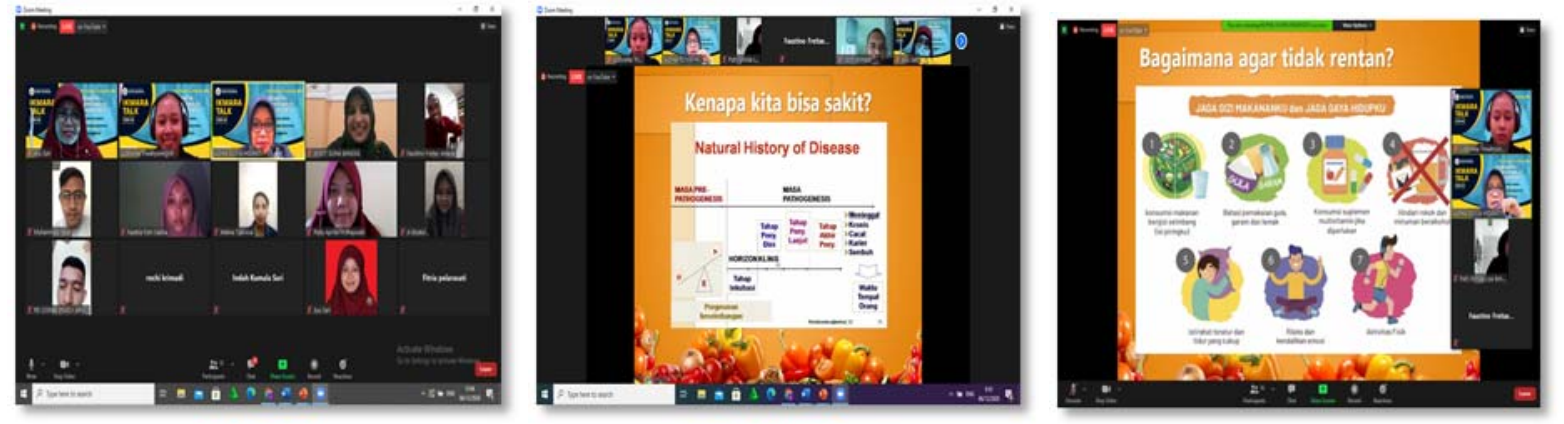

Gambar 2. Peserta kegiatan pengabdian kepada masyarakat

Gambar 3. Pelaksanaan kegiatan pengabdian kepada masyarakat

Setelah sesi diskusi dan tanya jawab dilaksanakan, peserta diminta untuk mengerjakan soal posttest dengan link https://forms.gle/8fGBXBq1dm64xKE89. Soal pre-test dan post-test berisi pertanyaan yang sama. Dari hasil pre-test dan post-test dilakukan evaluasi kegiatan terkait pemahaman responden tentang gizi seimbang serta minat mereka untuk menerapkan dalam kehidupan sehari-hari. Kegiatan ini juga diunggah di Youtube https://www.youtube.com/watch?v=O2beSNbjWv0\&t=994s agar dapat pula memberikan informasi kepada anggota IKMARA yang tidak mengikuti kegiatan ini melalui platform Zoom.

\section{HASIL DAN PEMBAHASAN}

Hasil

Kegiatan pengabdian masyarakat ini merupakan program awal dari rangkaian program pengabdian kepada masyarakat yang dilaksanakan oleh pelaksana. Hal ini dikarenakan program yang bertujuan untuk merubah perilaku dan sikap individu harus dilakukan secara terus menerus dan berkesinambungan. Pada tahap ini dilakukan sosialisasi kepada radiografer yang tergabung dalam IKMARA GUBAYO melalui "IKMARA TALK Series 1". Pada tahap ini target pelaksanaan pengabdian kepada masyarakat adalah para radiografer menjadi lebih mengetahui tentang gizi seimbang dan berminat untuk merubah kebiasaan atau perilaku mengkonsumsi gizi seimbang. Pada tahap pengabdian kepada masyarakat selanjutnya, radiografer diajak untuk menerapkan kebiasaan mengkonsumsi gizi seimbang dalam kehidupan seharihari.

Hasil pelaksanaan kegiatan pengabdian masyarakat dapat diketahui bahwa rata-rata tingkat pengetahuan sebelum diberikan edukasi tentang gizi seimbang adalah $60 \%$ namun setelah diberikan 
ABDIMAS: Jurnal Pengabdian Masyarakat Universitas Merdeka Malang Volume 6, No. 3, August 2021: 326-335

edukasi tentang gizi seimbang tingkat pengetahuan meningkat menjadi $85,45 \%$. Berdasarkan data pada Gambar 4, terdapat kenaikan tingkat pengetahuan peserta tentang gizi seimbang sebesar $25,45 \%$.
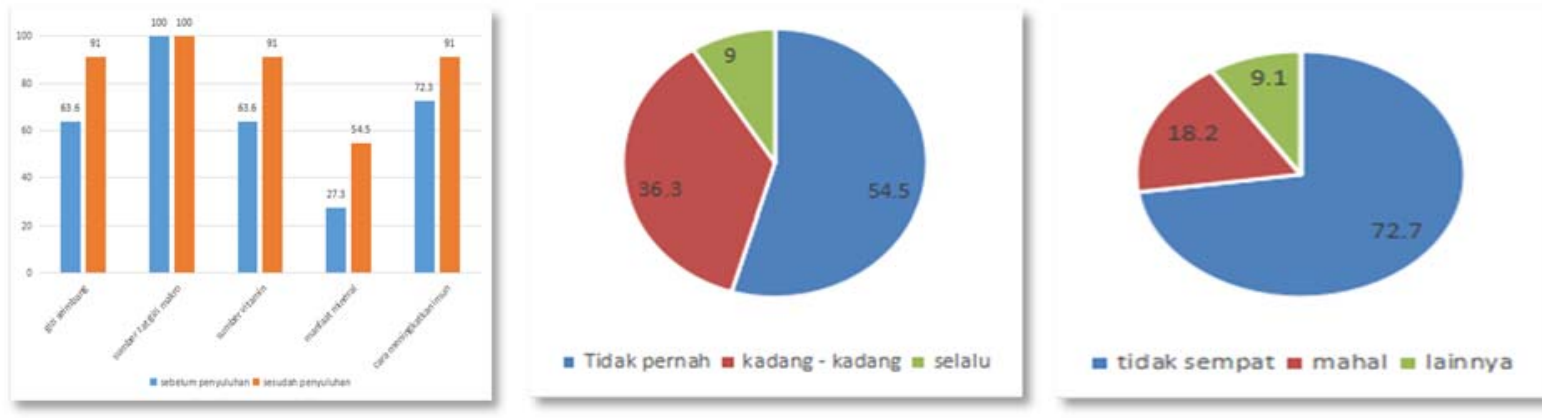

Gambar 4. Tingkat pengetahuan sebelum dan sesudah pemberian edukasi (dalam persen)

Gambar 5. Kebiasaan konsumsi gizi seimbang

Gambar 6. Alasan tidak mengkonsumsi gizi seimbang

Jika dilihat dari pertanyaan dalam kuesioner, terlihat bahwa pemahaman tentang gizi seimbang meningkat 27,4\%, pemahaman tentang sumber zat gizi makro tetap, pemahaman tentang sumber vitamin meningkat $27,4 \%$, pemahaman tentang manfaat mineral meningkat $27,2 \%$, dan pemahaman tentang cara meningkatkan imunitas meningkat $18,7 \%$.

Sebagian besar peserta (54,5\%) tidak mempunyai kebiasaan mengkonsumsi gizi seimbang dalam kehidupan sehari - hari. Kondisi ini diakibatkan tidak sempat dikarenakan kesibukan (72,7\%), sumber makanan yang mahal $(18,2 \%)$ dan tidak ada yang menyiapkan (9,1\%). Hal ini dapat dilihat dari Gambar 5 dan 6. Namun demikian, 89\% peserta mempunyai minat yang besar setelah mengetahui tentang pentingnya konsumsi gizi seimbang terutama dalam masa pandemi ini.

Selama proses pemberian edukasi sampai dengan sesi diskusi terdapat beberapa kendala yaitu signal yang tidak stabil pada peserta sehingga peserta terlihat keluar masuk platform Zoom. Selain itu, juga ada beberapa peserta yang meninggalkan kegiatan ditengah acara karena sedang bertugas di rumah sakit. Sehingga tidak mengikuti kegiatan post-test yang diadakan di akhir acara.

\section{Pembahasan}

Kegiatan pengabdian kepada masyarakat ini dilaksanakan dalam rangka meningkatkan pengetahuan dan minat radiografer anggota IKMARA GUBAYO dalam menerapkan konsumsi makanan dengan gizi seimbang dalam kehidupan sehari-hari. Dipilihnya radiografer anggota IKMARA GUBAYO sebagai sasaran kegiatan dikarenakan masih rendahnya kesadaran radiografer anggota IKMARA GUBAYO dalam menerapkan kebiasaan mengkonsumsi gizi seimbang. Radiografer muda diharapkan masih memiliki semangat yang tinggi untuk menerapkan pengetahuan yang diperolehnya dalam kehidupan sehari-hari. Selain itu, alasan lain dipilihnya radiografer muda dalam kegiatan ini adalah beban pekerjaan yang tinggi menyebabkan menurunkan nafsu makan sehingga cenderung mencari makanan yang praktis 


\section{Peningkatan Pengetahuan dan Minat Radiografer dalam Mengkonsumsi Gizi Seimbang di Era Pandemi COVID-19 \\ Alpha Olivia Hidayati, Ayu Wita Sari}

untuk dikonsumsi tanpa mempertimbangkan kandungan zat gizinya (Prasetiya, 2015). Kemungkinan ini mejadi lebih besar pada para radiografer yang belum berkeluarga. Hal ini terlihat pada hasil pengisian kuesioner yang menunjukkan bahwa sebagian besar responden menyatakan tidak sempat menyiapkan makanan dengan gizi seimbang dikarenakan kesibukan.

Usia yang masih muda mempunyai kecenderungan mudah untuk menerima informasi dan cepat memberikan tanggapan terhadap informasi yang diberikan (Notoadmodjo, 2010). Hal ini terlihat dari hasil pengisian kuesioner yang menunjukkan adanya pergeseran kategori dari tingkat pengetahuan cukup menjadi tingkat pengetahuan baik. Hal ini pula lah yang mendasari pemilihan sasaran dalam kegiatan pengabdian kepada masyarakat ini. Radiografer muda diharapkan mampu menjadi agen perubahan sikap tenaga kesehatan khususnya radiografer dalam mengkonsumsi makanan dengan gizi seimbang.

Berdasarkan hasil pengisian kuesioner terlihat bahwa pengetahuan tentang gizi seimbang, sumber zat gizi makro, sumber vitamin, manfaat mineral, dan cara meningkatkan imunitas tubuh meningkat. Hal ini menunjukkan bahwa penyampaian materi melalui audio-visual telah dapat membantu mengedukasi peserta tentang gizi seimbang. Kondisi ini dapat terjadi karena penggunaan platform Zoom memungkinkan terjadinya komuniksi dua arah antara peserta dan narasumber, sehingga penjelasan yang diberikan lebih mudah ditangkap. Terlebih lagi dalam penyampaian materi disertai dengan penjelasan berupa gambar dan tulisan. Hal ini sejalan dengan penelitian yang dilakukan oleh Endrawati (2015) yang menunjukkan bahwa dengan komunikasi dua arah mampu membawa perubahan pada pengetahuan, sikap, dan perilaku masyarakat dalam menanggapi penyakit Leptospirosis.

Setelah memperoleh informasi tentang pentingnya konsumsi makanan dengan gizi seimbang menimbulkan minat peserta pengabdian kepada masyarakat untuk menerapkan dalam kehidupan sehari-hari. Minat ini muncul dimungkinkan karena adanya kesadaran dari peserta bahwa mereka dalam posisi rentan terhadap COVID-19, menganggap penurunan imunitas merupakan masalah serius, meyakini efektivitas pencegahan melalui gizi seimbang, serta menyadari bahwa keuntungan dari perubahan perilaku lebih penting dari hambatan yang ada (Graeff et al., 1996).

\section{SIMPULAN DAN SARAN}

Pemberian edukasi kepada radiografer melalui penyuluhan secara daring mampu meningkatkan pengetahuan dan minat radiografer dalam komunitas IKMARA GUBAYO untuk mengkonsumsi gizi seimbang sebagai upaya meningkatkan imunitas tubuh di masa pandemi COVID-19.

Pentingnya untuk memberikan informasi secara terus menerus dan berkesinambungan kepada radiografer sehingga akan membentuk kebiasaan berperilaku mengkonsumsi makanan dengan gizi seimbang. Pemberian informasi juga bisa dilanjutkan dengan pemberian video informasi melalui Whatsapp Group sehingga informasi dan ajakan tidak hanya dilakukan saat pengabdian kepada masyarakat. 
ABDIMAS: Jurnal Pengabdian Masyarakat Universitas Merdeka Malang Volume 6, No. 3, August 2021: 326-335

\section{UCAPAN TERIMA KASIH}

Penulis mengucapkan terima kasih kepada IKMARA (Ikatan Alumni Mahasiswa Radiologi) Stikes Guna Bangsa yang telah memberikan waktu dan kesempatan terhadap pengabdian ini di sela bekerja di berbagai rumah sakit.

\section{DAFTAR PUSTAKA}

Agustin, F., Fayasari, A., \& Dewi, G. K. (2018). Pengetahuan, sikap, dan perilaku gizi seimbang terhadap status gizi lebih pada pegawai Rumah Sakit Penyakit Infeksi Sulianti Saroso Jakarta Utara. Ilmu Gizi Indonesia, 1(2), 93-103. https://doi.org/10.35842/ilgi.v1i2.19

Andriani, M., \& Wijatmadi, B. (2012). Pengantar Gizi Masyarakat. Jakarta: Kencana Prenada Media Group.

Endrawati, E. (2015). Penerapan komunikasi kesehatan untuk pencegahan penyakit Leptospirosis pada masyarakat Desa Sumberagung, Kecamatan Moyudan, Sleman Yogyakarta. Jurnal Komunikasi, 7(1), 1-25. http://dx.doi.org/10.24912/jk.v7i1.4

Graeff, J. A., Elder, J. P., \& Booth, E. M. (1996). Komunikasi untuk Kesehatan dan Perubahan Perilaku (trans: Mubasyir Hasanbasri). Yogyakarta: Gadjah Mada University Press.

Haryanti, H., Aini F. \& Purwaningsih P. (2013). Hubungan beban kerja dengan stres kerja perawat di instalasi gawat darurat RSUD Kabupaten Semarang. Jurnal Manajemen Keperawatan, 1(1).

Hidayah, S. N., Izah, N., \& Andari, I. D. (2020). Peningkatan imunitas dengan konsumsi Vitamin C dan gizi seimbang bagi ibu hamil untuk cegah Corona di Kota Tegal. Jurnal ABDINUS: Jurnal Pengabdian Nusantara, 4(1), 170-174. https://doi.org/10.29407/ja.v4i1.14641

Kementrian Kesehatan Republik Indonesia. (2020). Apa yang Harus Dilakukan Masyarakat untuk Cegah Penularan COVID-19. Jakarta: Kementrian Kesehatan Republik Indonesia.

Keputusan Menteri Kesehatan Republik Indonesia No. 1014/Menkes/SK/XI/2008 tentang Standar Pelayanan Radiologi Diagnostik

KPCPEN. (2020). Data Sebaran Virus COVID-19 di Indonesia. Komite Penanganan COVID-19 dan Pemulihan Ekonomi Nasional. Retrieved from: https://COVID19.go.id/. (Diakses tanggal 4 Desember 2020).

Kurniawati, D., \& Solikhah, S. (2012). Hubungan kelelahan kerja dengan kinerja perawat di bangsal rawat inap Rumah Sakit Islam Fatimah Kabupaten Cilacap. Kes Mas: Jurnal Fakultas Kesehatan Masyarakat, 6(2), 162-232.

Mayasari, D., \& Pratiwi, A. (2009). Hubungan respon imun dan stres dengan tingkat kekambuhan demam tifoid pada masyarakat di Wilayah Puskesmas Colomadu Karanganyar. Berita Ilmu Keperawatan, 2(1), 13-18.

Muchtadi, D. (2009). Pengantar Ilmu Gizi. Bandung: Alfabeta.

Najmah. (2015). Epidemiologi Penyakit Menular. Palembang: Universitas Sri Wijaya.

Notoadmodjo S. (2010). Promosi Kesehatan dan Ilmu Perilaku. Jakarta: Rineka Cipta. 
Peningkatan Pengetahuan dan Minat Radiografer dalam Mengkonsumsi Gizi Seimbang di Era Pandemi COVID-19 Alpha Olivia Hidayati, Ayu Wita Sari

Prasetiya, C. H. (2015). Efektifitas Pendidikan kesehatan terhadap peningkatan pengetahuan keluarga tentang hipertensi. Mutiara Medika: Jurnal Kedokteran dan Kesehatan, 15(1), 67-74.

https://doi.org/10.18196/mmjkk.v15i1.2496

Pratami, T. J., Widajanti, L., \& Aruben, R. (2016). Hubungan penerapan prinsip pedoman gizi seimbang dengan status gizi mahasiswa S1 Departemen Ilmu Gizi Fakultas Kesehatan Masyarakat Universitas Diponegoro Semarang. Jurnal Kesehatan Masyarakat, 4(4), 561-569.

Runtu, V. V., Pondaag, L., \& Hamel, R. (2018). Hubungan beban kerja fisik dengan stres kerja perawat di ruang instalasi rawat inap Rumah Sakit Umum GMIM Pancaran Kasih Manado. Jurnal Keperawatan, 6(1), 1-7.

Yurni, A. F., \& Sinaga, T. (2017). Pengaruh pendidikan gizi terhadap pengetahuan dan praktik membawa bekal menu seimbang anak sekolah dasar. Media gizi indonesia, 12(2), 183-190. http://dx.doi.org/10.20473/mgi.v12i2.183-190

Yosephin, B. (2018). Tuntunan Praktis Menghitung Kebutuhan Gizi. Yogyakarta: Andi Offset. 